\title{
Study of the gas-phase fragmentation behaviour of sulfonated peptides
}

\author{
Sanja Škulj, Marko Rožman
}

\section{A B S T R A C T}

A series of singly and doubly protonated peptides bearing sulfonated residue have been studied, using both experiment and molecular modelling, to elucidate fragmentation chemistry of sulfonated peptides. Collision-induced dissociation mass spectra indicate that the sulfo group loss (neutral loss of $80 \mathrm{Da}$ ) is the dominant dissociation channel. Modelling results suggest the proton transfer mechanism, where upon vibrational excitation, the acidic side chain proton is transferred from the sulfo group hydroxyl to the ester oxygen resulting in S O bond cleavage and formation of the unmodified hydroxyl containing residue and $\mathrm{SO}_{3}$. Conformations associated with potential energy profile of the reaction imply the charge remote nature of the proposed mechanism. The proposed proton transfer mechanism was compared with the intramolecular nucleophilic substitution ( $\left.\mathrm{S}_{\mathrm{N}} 2\right)$ mechanism, the main pathway suggested for neutral loss of phosphoric acid from phosphopeptides. Both pathways (proton transfer and $\mathrm{S}_{\mathrm{N}} 2$ ) are available for sulfonated and phosphorylated peptides; however, each posttranslational modification favours different mechanism. The change of the bond dissociation enthalpies and the ability of stabilising the transition state structures are demonstrated as main factors responsible for each posttranslational modification activating a different pathway.

\section{Introduction}

One of the most common uses of mass spectrometry (MS) is obtaining the structure or sequence of an ion being analysed. The gas-phase approach to generate structure-specific information involves use of tandem MS and subsequent interpretation of fragment ion spectra. In the tandem MS of the protonated peptides, the ion of interest is isolated and then (usually) dissociated via low energy vibration excitation (either collision-induced dissociation (CID) or infrared multi-photon dissociation (IRMPD)). Assignment of molecular structures to the tandem MS spectra greatly relies on the fragmentation models used. The most comprehensive set of rules for understanding of dissociation mechanisms of protonated peptides is known as the mobile proton model [1-5]. The model (introduced by Vicki Wysocki and Simon Gaskell) assumes that in the activated protonated peptide, ionising proton(s) can migrate to various sites, thus triggering charge-directed fragmentation mechanisms [1-5]. The mobile proton concept has been successfully applied in numerous studies of fragmentation mechanisms of various tryptic and non-tryptic peptides, cyclic peptides and peptides bearing some posttranslational modification (PTM) [1-7].

Sulfonation, common PTM in multicellular eukaryotes, represents addition of sulfonic acid group to a protein. Modification is detected on Tyr (mainly), Ser and Thr residues and has the same nominal mass increase as phosphorylation (+80 Da) [8-10]. Thus, it was suggested that rates of protein sulfonation could be underestimated due to a coexistence of both phosphorylated and sulfonated (isobaric) forms of the same peptide [8-10]. Use of ultra-high resolution (accurate mass) measurements, ultraviolet and infrared photodissociation spectroscopy techniques demonstrated that PTM modified isobaric peptides could be distinguished [11-13]. Despite the advantages of high-resolution mass measurements, photodissociation techniques and electron capture/transfer dissociation [14], CID remains the generally used approach for sulfonation assignments [8-10,15-17]. Protonated sulfonated peptides analysed by CID undergo the facile neutral loss of the sulfur trioxide $\left(\mathrm{SO}_{3}\right.$, loss of $80 \mathrm{Da}$ ) from their precursor ions [8-10,15-17]. The neutral loss precedes any peptide backbone fragmentation, thus limiting precise localization of the sulfonation sites. Understanding of the gas-phase dissociation pathways of sulfonated peptides is very limited. Recently, Patrick et al. preformed structural investigation of protonated sulfoserine dissociation pathways [18]. Low-energy CID of protonated sulfoserine produced two major 
product ions: 3-member aziridine ring structure attributed to the neutral loss of $98 \mathrm{Da}$ (loss of $\mathrm{H}_{2} \mathrm{SO}_{4}$ ) and a structure identical to the protonated serine was related to the loss of $80 \mathrm{Da}$ (loss of $\mathrm{SO}_{3}$ ). However, insights at the peptide level are still missing.

Better understanding of the fragmentation chemistry of sulfonated peptides would be of value. Previously, we provided a description of the gas-phase dissociation of phosphorylated peptides [7]. One may consider sulfonation and phosphorylation as similar because both modifications represent highly acidic monoesters of their respective acids and give rise to a nominal mass increase of $80 \mathrm{Da}$ However, neutral loss during vibrational excitation from protonated sulfopeptides is associated to $\mathrm{SO}_{3}$ [8-10] while that from phosphopeptides (phosphorylated Ser and Thr residues) is associated mainly to elimination of $\mathrm{H}_{3} \mathrm{PO}_{4}$ [6,7], i.e. suggesting activation of different dissociation pathways.

In this work, through the combination of low-energy CID experiments and molecular modelling, we present the description of the fragmentation mechanisms of sulfonated peptides. Furthermore, we complement the present findings on sulfopeptides with our previous results on phosphopeptides and attempt to understand why a certain fragmentation pathway is related to specific PTM.

\section{Materials and methods}

\subsection{Materials}

Analytes and reagents were obtained from Sigma-Aldrich (St Louis, USA) and used without further purification. Peptides TSQLL, SAALSLLR, SAALYLLR and their posttranslational modified variants were obtained from PolyPeptide Laboratories (Strasbourg, France). Peptide sulfonation was achieved using the procedure described in ref. [9]. Briefly, peptides were dissolved in trifluoroacetic acid and reacted with $5 \%$ chlorosulfonic acid $\left(\mathrm{ClSO}_{3} \mathrm{H}\right)$ at room temperature for $20 \mathrm{~min}$ The reaction was terminated adding $\mathrm{H}_{2} \mathrm{O}$ and the solution neutralised with $\mathrm{NH}_{4} \mathrm{OH}$.

\subsection{Mass spectrometry}

MS and tandem MS experiments were carried out on the amaZon ion trap mass spectrometer (Bruker Daltonik, Bremen, Germany). Peptides were dissolved in $50 / 50$ ethanol/water with $0.1 \%$ formic acid to obtain $1 \mu \mathrm{M}$ concentration. Solution was introduced into the electrospray ionisation source by direct infusion at the flow rate of $75 \mu \mathrm{L} / \mathrm{h}$. The capillary voltage was set at $-4500 \mathrm{~V}$ while high voltage end plate offset was $-500 \mathrm{~V}$. The temperature and the flow rate of the drying gas were set at $205^{\circ} \mathrm{C}$ and $5 \mathrm{~L} / \mathrm{min}$, respectively. The electrospray ionisation source parameters were optimised to allow an efficient ionisation and to reduce the in-source fragmentation of precursor ions. The isolation width of the precursor ion was set at $2 \mathrm{Da}$ The CID excitation time was $40 \mathrm{~ms}$ and the amplitude was in the $0.4-1 \mathrm{~V}$ range, depending on a precursor. All spectra were acquired in the positive ion mode using a scan range from $\mathrm{m} / \mathrm{z} 100$ to 1100. DataAnalysis 4.0 and BioTools 3.2 (Bruker Daltonik GmbH, Bremen, Germany) were used for spectra analysis and extraction of the MS and tandem MS data.

\subsection{Computational methods}

In order to gain initial understanding of the potential energy surface (PES) associated with loss of the sulfate modification, the proposed pathways were first established on the small model system, $\mathrm{CH}_{3} \mathrm{COsSerNHCH}_{3}$, and then further evaluated on the test peptides TsSQLL and SAALSSLLR. Both the small model system and the peptides were optimised at the B3LYP/6-31G(d) level of theory. Both the functional and the basis set represent a good compromise for obtaining satisfactory geometries and approximate relative energies, as demonstrated in the theoretical studies of similar systems $[7,19,20]$. Stationary points (i.e. the minima and transition states on the potential energy surface) were identified by the harmonic frequency analysis. Transition state structures were additionally tested by the Intrinsic Reaction Coordinate (IRC) analysis. In order to get a more accurate description of dissociation energies, calculations using the G3(MP2)//B3LYP protocol [21] were performed on a restricted number of the small model system conformations. The G3(MP2)//B3LYP results were correlated with series of the single point energy calculations in order to pinpoint a model suitable for use on the test peptides. The B2PLYP, B3LYP, M062X and MP2 methods were used in combination with the different basis sets: $6-31 G(d), 6-31+G(d), 6-31++G(d, p), 6-$ $311++G(d, p)$ and TZVP. The smallest mean absolute deviation was found for energies calculated at the B3LYP/TZVP level of theory.

Combination of quenched dynamics and simulated annealing with the AMBER 99 force field was used to sample the potential energy surface of the test peptides (TSQLL and SAALSLLR) by the protocol identical to that previously used [7,22]. Final structures were reoptimised using the B3LYP/6-31G(d) level of theory and the lowest energy structure was considered as the representative structure. From the representative structure, the potential energy profiles of dissociation pathways were constructed at the B3LYP/TZVP//B3LYP/6-31G(d) level. The Rice-Ramsperger-KasselMarcus (RRKM) kinetic theory was used to describe the reaction rate as a function of internal energy of peptides.

All quantum mechanic calculations were established using the Gaussian 09 [23], molecular dynamic simulations were carried out using the AMBER 12 [24] and RRKM calculations were obtained using the MassKinetics 1.15 [25].

\section{Results and discussion}

\subsection{CID of sulfonated peptides - mobile proton environment}

The low-energy CID product ion spectra were examined in order to set initial understanding of the gas-phase fragmentation behaviour of sulfonated peptides. The spectra obtained by dissociation of the doubly protonated SAALSSLLR and SAALSYLLR exhibit a very intense neutral loss of $80 \mathrm{Da}$, Fig. 1 . The sulfo group loss from the precursor ion as well as from $\mathrm{b}$ and $\mathrm{y}$ product ions dominates all tandem MS spectra analysed in this work (Fig. 1 and Fig. S1 supplementary data). However, in some cases, small portion of b and $y$ ions retain the sulfo group and enable characterisation of the peptides (Fig. 1). Those ions are associated with $5.7 \%$ of the total ion intensity of all identified ions (in this work) and are not readily observed in tandem MS spectra of sulfonated peptides (e.g. Fig. S1 b and ref. $[8-10,16])$. Therefore, it is sometimes difficult to obtain site-specific information on the location of the sulfo group.

Although the tandem MS spectra of peptides described here represent only an example, together with previous results $[9,16]$ they indicate that the sulfo group loss is the dominant dissociation channel in the collisionally activated peptides where ionising proton can migrate to various sites (the mobile proton environment). It would be of interest to collect more sulfopeptide tandem MS spectra obtained on different instruments in order to statistically characterise fragmentation behaviour but this is out of the scope of the present paper.

The mechanism, which could be associated with the sulfo group loss, includes the proton transfer from the sulfo group hydroxyl to the ester oxygen and consequent formation of the hydroxyl group and $\mathrm{SO}_{3}$ (Scheme $1 \mathrm{a}$ ). The mechanism is similar to the one associated with the loss of metaphosphoric acid in phosphorylated 

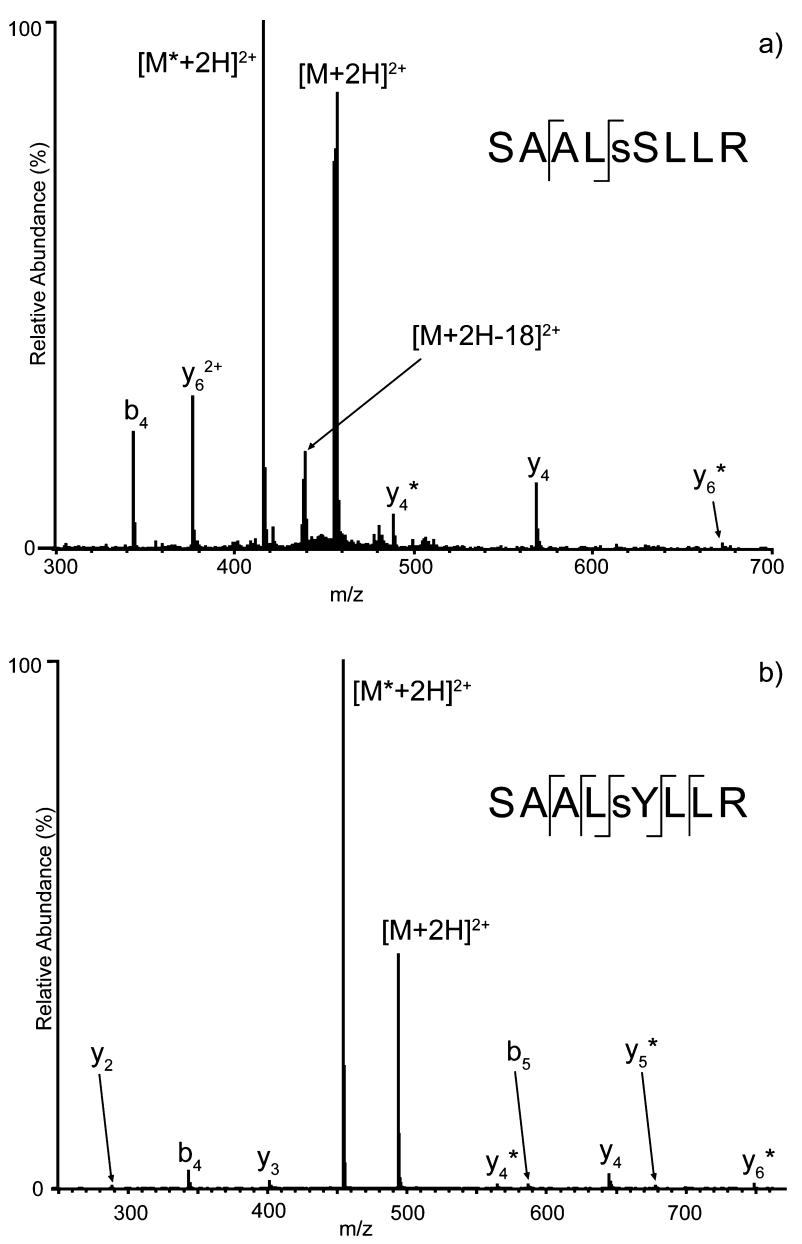

Fig. 1. CID tandem MS product ion spectra of the doubly protonated (a) SAALSSLLR and (b) SAALsYLLR. ${ }^{*}-80 \mathrm{Da}\left(-\mathrm{SO}_{3}\right)$.

peptides [7] and was hypothesised for the sulfo group loss from sulfoserine [18].

The potential energy profile for the sulfo group loss from SAALSSLLR peptide is shown in Fig. 2, together with the optimised structures of the energy minima and transition state. As hypothesised, the mechanism includes transfer of the acidic side

a)<smiles>[R]NC(=O)C(CO)NC([R])=O</smiles>

b)<smiles>[R]NC(=O)C1COC([R])=N1</smiles>

Scheme 1. . (a) Proton transfer mechanism and (b) intramolecular nucleophilic substitution $\left(\mathrm{S}_{\mathrm{N}} 2\right)$ mechanism.

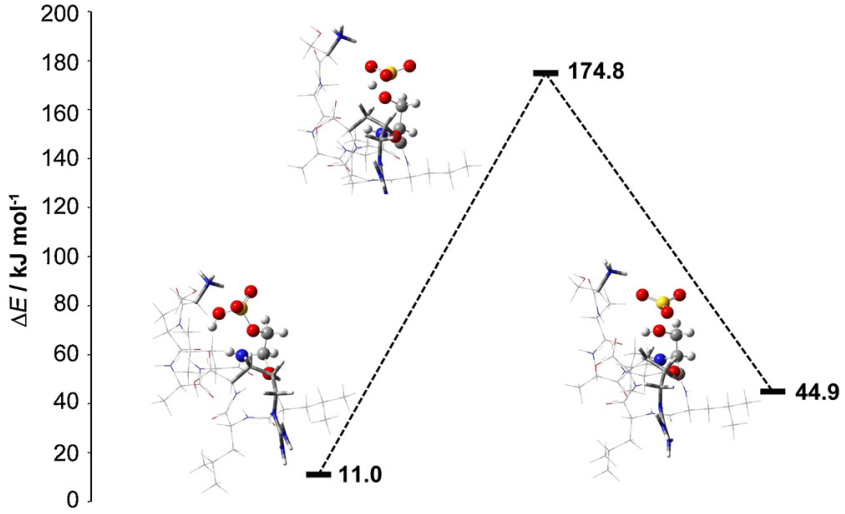

Fig. 2. Schematic representation of the potential energy profile of the sulfo group loss from the doubly protonated SAALSSLLR peptide. The relative energies are calculated at the B3LYP/TZVP//B3LYP/6-31G(d) level of theory with respect to the most stable SAALsSLLR conformer found. Magnified structures with interatomic distances are available as supplementary data (Fig. S7).

chain proton from the sulfo group hydroxyl to the ester oxygen. In the transition state, the sulfo group is additionally stabilised via interaction with protonated amino terminus. Although there is a possibility for activating the ionising proton from the amino terminus during reaction, there is no evidence that the ionising proton is involved in the mechanism. The protonated amino terminus-sulfo group interaction could suggest a charge-directed pathway where the charged amino terminus could make the sulfo hydroxyl group a more electron deficient and thus a more efficient proton donor. The role of the ionising proton in the proton transfer mechanism was further examined with singly protonated TsSQLL peptide (the mobile proton environment). In TSSQLL peptide, the protonated amino terminus and the sulfonated serine side chain are very close; therefore, involvement of ionising proton should be evident. However, the identical reaction mechanism in protonated TsSQLL peptide does not require interaction of the sulfo group with the protonated amino terminus, suggesting the charge remote nature of the sulfo group loss pathway (Fig. S2 - supplementary data). Thus, observed interaction in SAALSSLLR peptide can be attributed to the secondary structure stabilisation via hydrogen bonds. Upon $\mathrm{SO}_{3}$ abstraction from the sulfonated side chain, the side chain residue takes the form structurally analogous to the unmodified hydroxylcontaining residue, consistent with the IRMPD observations on sulfoserine [18]. At this point, $\mathrm{SO}_{3}$ molecule probably interacts with peptide and consequently the ion-molecule complex dissociates making the neutral loss of $\mathrm{SO}_{3}$ a two-step process (abstraction and ion-molecule complex dissociation), in accordance with observations of phosphopeptides dissociation dynamics [26].

Reaction barrier for sulfo group loss of the doubly protonated SAALsSLLR peptide is $174.8 \mathrm{~kJ} \mathrm{~mol}^{-1}$. Calculated unimolecular reaction rates (by the RRKM theory) show that reaching ms time range pathway requires $1180 \mathrm{~kJ} \mathrm{~mol}^{-1}$ while increase up to $1880 \mathrm{~kJ} \mathrm{~mol}^{-1}$ is needed for $\mu$ s time range (Fig. S3 - supplementary data). Rate energy dependences of $\mathrm{SO}_{3}$ loss pathway match literature available average internal energy values of similar size peptides (approximately 900 for ms time range and $1700 \mathrm{~kJ} \mathrm{~mol}^{-1} \mu \mathrm{s}$ time range) [27].

\subsection{CID of sulfonated peptides - limited proton mobility}

The precursor ion and backbone fragments in the low-energy CID spectra of peptides under the mobile proton environment exhibit a very intense neutral loss of $80 \mathrm{Da}$ Loss of the sulfo moiety is even more prominent under the limited proton mobility, Fig. 3. 

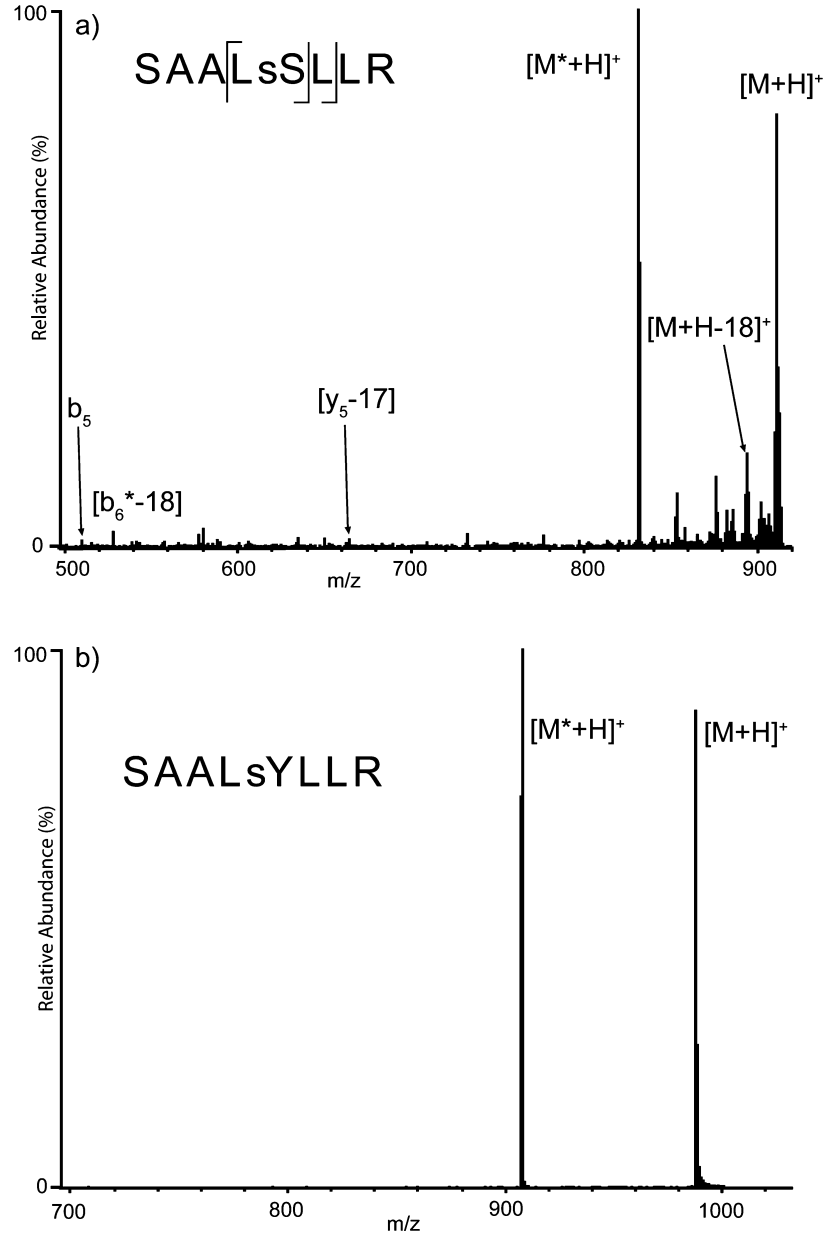

Fig. 3. CID tandem MS product ion spectra of the singly protonated (a) SAALsSLLR and (b) SAALsYLLR. * $-80 \mathrm{Da}\left(-\mathrm{SO}_{3}\right)$.

Singly protonated SAALsSLLR and SAALsYLLR peptides preferentially eliminate the modification even before backbone fragmentation occurs. Deposition of the larger amounts of additional vibronic energy sometimes may result in additional peptide backbone fragmentation, in accordance with already documented findings [16].

Assessment of the potential energy surface of the sulfo group loss for the singly protonated SAALSSLLR reveals identical charge remote mechanism as the one under the mobile proton environment (Fig. 1a). However, there is no interaction between the sulfo moiety and the arginine guanidino group.

According to RRKM calculations, the sulfo group loss from the precursor ion occurs at the millisecond time scale at the internal energy of $1010 \mathrm{~kJ} \mathrm{~mol}^{-1}$ (Fig S4 - supplementary data). Internal energy window for the peptide bond cleavage is from 1000 to $1700 \mathrm{~kJ} \mathrm{~mol}^{-1}[27,28]$, suggesting elimination of the sulfo moiety from the precursor ion as the principal dissociation channel, which is in agreement with our experimental observations.

\subsection{Neutral loss of PTM: sulfonated vs. phosphorylated peptides}

The major fragmentation pathway occurring from energised protonated sulfopeptide originates by loss of $\mathrm{SO}_{3}$ ( $-80 \mathrm{Da}$ ), Fig. 1. A phospho modification containing peptides (except pTyr residue), in contrast, shows pronounced peaks related to elimination of $\mathrm{H}_{3} \mathrm{PO}_{4}(-98 \mathrm{Da})$ (tandem MS spectra of TpSQLL and SAALPSLLR in Fig. S5 - supplementary data). Neutral loss of the phosphoric acid involves the charge-directed intramolecular nucleophilic substitution $\left(\mathrm{S}_{\mathrm{N}} 2\right)$ mechanism (Scheme $1 \mathrm{~b}$ ) while sulfur trioxide loss
Table 1

The proton transfer and $\mathrm{S}_{\mathrm{N}} 2$ mechanism reaction barriers (in $\mathrm{kJ} \mathrm{mol}^{-1}$ ) calculated at the B3LYP/TZVP//B3LYP/6-31G(d) level of theory. The reaction barriers were calculated with respect to the most stable peptide conformation. Total electronic energies (in Eh) and atomic coordinates are available in supporting data file (Table S1).

\begin{tabular}{lllc}
\hline \multirow{2}{*}{ Peptide } & Charge state & \multicolumn{2}{l}{ Reaction mechanism } \\
\cline { 3 - 4 } & & Proton transfer & $\mathrm{S}_{\mathrm{N}} 2$ \\
\hline TsSQLL & 1 & 148.9 & 157.1 \\
TpSQLL & 1 & 165.7 & 134.6 \\
SAALsSLLR & 1 & 155.1 & 167.9 \\
SAALpSLLR & 1 & 173.5 & 166.9 \\
SAALsSLLR & 2 & 174.8 & 181.2 \\
SAALpSLLR & 2 & 200.4 & 180.1 \\
Model system $(\mathrm{sS})^{\mathrm{a}}$ & 1 & 111.1 & 89.3 \\
Model system $(\mathrm{pS})^{\mathrm{a}}$ & 1 & 160.6 & 93 \\
\hline
\end{tabular}

a Reaction barrier of the model system was calculated using G3(MP2)//B3LYP protocol.

is related to charge remote proton transfer mechanism (Fig. 2a). In both modifications, the presence of other modification dominant mechanisms can be observed to a smaller extent, i.e. $\mathrm{S}_{\mathrm{N}} 2$ mechanism in sulfonated peptides (loss of sulfuric acid, -98 Da e.g. Fig. S1 - supplementary data) and proton transfer mechanism in phosphorylated peptides (loss of metaphosphoric acid, $-98 \mathrm{Da}$, e.g. ref. [6]). Both modifications represent similar highly acidic monoesters and have potential for proton transfer and intramolecular nucleophilic substitution; however during collisional activation different dissociation channels were dominant.

To compare both mechanisms, potential energy profiles for phosphorylated/sulfonated SAALSLLR and TSQLL peptides were constructed and the corresponding reaction barriers at the B3LYP/TZVP//B3LYP/6-31G(d) level of theory are given in Table 1. From reactions barriers, it follows that moving from sulfonated to phosphorylated peptide increases the proton transfer barrier height while $S_{N} 2$ threshold remains roughly the same or slightly lower in phosphorylated peptides. An explanation is offered by inspecting the nature of functional groups.

In the intramolecular nucleophilic substitution reaction, the alkyl group-ester oxygen bond is cleaved while in the proton transfer reaction, the ester oxygen-sulfur/phosphor bond is cleaved. $\mathrm{S}_{\mathrm{N}} 2$ reaction breaks the same bond regardless of PTM while proton transfer mechanism breaks a different bond. Regarding the bond strength, it is useful to consider mean bond dissociation enthalpy since it may provide rough estimate of relative bond strength. S-O bond dissociation enthalpy is $37 \mathrm{~kJ} \mathrm{~mol}^{-1}$ lower than $\mathrm{P}-\mathrm{O}$ bond dissociation enthalpy, suggesting that $\mathrm{S}-\mathrm{O}$ bond is weaker than $\mathrm{P}-\mathrm{O}$ [29]. $\mathrm{S}_{\mathrm{N}} 2$ barrier lowering in peptides bearing phospho modification may be attributed to extra hydroxylic group available at phospho residue which enables additional hydrogen bond formation and stabilisation of the transition state structure. Intramolecular nucleophilic substitution requires side chain-polypeptide chain interaction while proton transfer mechanism is restricted only to the side chain; thus, $\mathrm{S}_{\mathrm{N}} 2$ mechanism requires "more defined" transition state conformation and therefore it is more susceptible to stabilisation by additional hydrogen bond. The small model system (see Section 2) can provide indicative information about the barriers taking into account the bond strength and (on the other hand) it is free of secondary structure stabilisation effects. $S_{\mathrm{N}} 2$ barrier estimated at the sulfo and phospho model systems is roughly the same while the proton transfer barrier for the phospho model system is $\sim 50 \mathrm{~kJ} \mathrm{~mol}^{-1}$ which is higher than for sulfo (Table 1).

In both mechanisms, the geometry of transition state is relatively close to the product geometry and consequently RRKM curves will have similar shape (Fig. 4 and Fig. S6). Since the size of the precursor does not change, the main difference between 


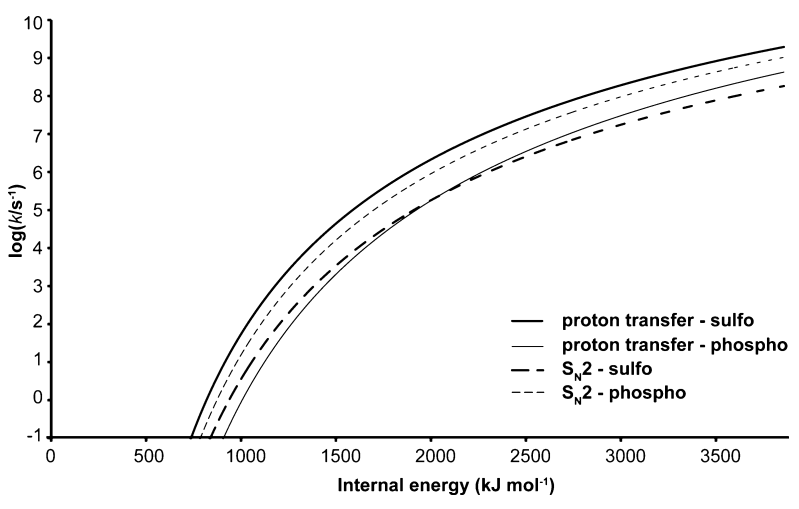

Fig. 4. RRKM theory unimolecular reaction rate constants for the proton transfer and $\mathrm{S}_{\mathrm{N}} 2$ pathway in doubly protonated SAALSSLLR and SAALPSLLR peptide.

RRKM curves will be determined by activation energy (reaction threshold). Accordingly, change in modification from sulfonation to phosphorylation will raise proton transfer barrier (and lower $\mathrm{S}_{\mathrm{N}} 2$ barrier) making nucleophilic substitution mechanism predominant (Fig. 4 and Fig S6). RRKM plots show dominance of proton transfer mechanism for sulfonated peptides and dominance of $\mathrm{S}_{\mathrm{N}} 2$ pathway in phosphorylated peptides, which is in agreement with our suggestions and experimental data (Fig. 4 and Fig S6).

\section{Conclusions}

Combined experimental and theoretical investigation of the gasphase dissociation behaviour of sulfonated peptides yielded the following results.

Regardless of proton mobility environment, neutral loss of $80 \mathrm{Da}$ from sulfonated peptides is related to the charge remote proton transfer mechanism. Molecular modelling predicts that during vibrational excitation, the acidic side chain proton is transferred from sulfo group hydroxyl to the ester oxygen. Protonation of the ester oxygen leads to $\mathrm{S}-\mathrm{O}$ bond cleavage and to formation of unmodified hydroxyl containing residue and $\mathrm{SO}_{3}$.

In comparison with other dissociation channels (e.g. b/y ion formation), the neutral loss product ion(s) should be dominant in the tandem MS spectrum. Furthermore, with limiting proton mobility, their abundance should increase even more.

Although identical dissociation pathways (the proton transfer and the intramolecular nucleophilic substitution) are available for sulfonated and phosphorylated peptides, each PTM activates different mechanism. Preference of the proton transfer mechanism in sulfonated peptides is a consequence of the fact that the $\mathrm{S}-\mathrm{O}$ bond is weaker compared to $\mathrm{P}-\mathrm{O}$ bond. On the other hand, due to the stronger $\mathrm{P}-\mathrm{O}$ bond and the possibility of additional stabilisation of the transition state (additional $\mathrm{OH}$ group), phosphorylated peptides follow the intramolecular nucleophilic substitution mechanism.

\section{Acknowledgements}

This manuscript is dedicated to Prof. Simon J. Gaskell in happy celebration of his 65th birthday. The Ministry of Science, Education and Sports of Republic of Croatia supported this work.

\section{Appendix A. Supplementary data}

Supplementary data associated with this article can be found, in the online version, at http://dx.doi.org/10.1016/j.ijms.2015.07.023

\section{References}

[1] O. Burlet, C.Y. Yang, S.J. Gaskell, Influence of cysteine to cysteic acid oxidation on the collision-activated decomposition of protonated peptides: evidence for intraionic interactions, J. Am. Soc. Mass Spectrom. 3 (1992) 337-344.

[2] A.L. McCormack, Á. Somogyi, A.R. Dongré, V.H. Wysocki, Fragmentation of protonated peptides: surface-induced dissociation in conjunction with a quantum mechanical approach, Anal. Chem. 65 (1993) 2859-2872.

[3] K.A. Cox, S.J. Gaskell, M. Morris, J. Whiting, Role of the site of protonation in the low-energy decompositions of gas-phase peptide ions, J. Am. Soc. Mass Spectrom. 7 (1996) 522-531.

[4] A.R. Dongreí, J.L. Jones, A. Somogyi, V.H. Wysocki, Influence of peptide composition, gas-phase basicity, and chemical modification on fragmentation efficiency: evidence for the mobile proton model, J. Am. Chem. Soc. 118 (1996) 8365-8374.

[5] R. Boyd, A. Somogyi, The mobile proton hypothesis in fragmentation of protonated peptides: a perspective, J. Am. Soc. Mass. Spectrom. 21 (2010) 1275-1278.

[6] A.M. Palumbo, G.E. Reid, Evaluation of gas-phase rearrangement and competing fragmentation reactions on protein phosphorylation site assignment using collision induced dissociation-MS/MS and MS ${ }^{3}$, Anal. Chem. 80 (2008) 9735-9747.

[7] M. Rožman, Modelling of the gas-phase phosphate group loss and rearrangement in phosphorylated peptides, J. Mass. Spectrom. 46 (2011) 949-955.

[8] C. Seibert, T.P. Sakmar, Toward a framework for sulfoproteomics: synthesis and characterization of sulfotyrosine-containing peptides, Pept. Sci. 90 (2007) 459-477.

[9] K.F. Medzihradszky, Z. Darula, E. Perlson, M. Fainzilber, R.J. Chalkley, H. Ball, D. Greenbaum, M. Bogyo, D.R. Tyson, R.A. Bradshaw, A.L. Burlingame, O-sulfonation of serine and threonine: mass spectrometric detection and characterization of a new posttranslational modification in diverse proteins throughout the eukaryotes, Mol. Cell. Proteomics 3 (2004) 429-440.

[10] K.A. Dave, F. Whelan, C. Bindloss, S.G.B. Furness, A. Chapman-Smith, M.L Whitelaw, J.J. Gorman, Sulfonation and phosphorylation of regions of the dioxin receptor susceptible to methionine modifications, Mol. Cell. Proteomics 8 (2009) 706-719.

[11] R.E. Bossio, A.G. Marshall, Baseline resolution of isobaric phosphorylated and sulfated peptides and nucleotides by electrospray ionization FTICR MS: another step toward mass spectrometry-based proteomics, Anal. Chem. 74 (2002) 1674-1679.

[12] A.L. Patrick, C.N. Stedwell, N.C. Polfer, Differentiating sulfopeptide and phosphopeptide ions via resonant infrared photodissociation, Anal. Chem. 86 (2014) 5547-5552.

[13] M.R. Robinson, K.L. Moore, J.S. Brodbelt, Direct identification of tyrosine sulfation by using ultraviolet photodissociation mass spectrometry, J. Am. Soc. Mass Spectrom. 25 (2014) 1461-1471.

[14] K.F. Medzihradszky, S. Guan, D.A. Maltby, A.L. Burlingame, Sulfopeptide fragmentation in electron-capture and electron-transfer dissociation, J. Am. Soc. Mass Spectrom. 18 (2007) 1617-1624.

[15] T. Yagami, K. Kitagawa, S. Futaki, Liquid secondary-ion mass spectrometry of peptides containing multiple tytosine-O-sulfates, Rapid Commun. Mass Spectrom. 9 (1995) 1335-1341.

[16] J.F. Nemeth-Cawley, S. Karnik, J.C. Rouse, Analysis of sulfated peptides using positive electrospray ionization tandem mass spectrometry, J. Mass Spectrom. 36 (2001) 1301-1311.

[17] J.L. Wolfender, F. Chu, H. Ball, F. Wolfender, M. Fainzilber, M.A. Baldwin, A.L. Burlingame, Identification of tyrosine sulfation in Conus pennaceus conotoxins $\alpha$-PnIA and $\alpha$-PnIB: further investigation of labile sulfo- and phosphopeptides by electrospray, matrix-assisted laser desorption/ionization (MALDI) and atmospheric pressure MALDI mass spectrometry, J. Mass Spectrom. 34 (1999) 447-454.

[18] A.L. Patrick, C.N. Stedwell, B. Schindler, I. Compagnon, G. Berden, J. Oomens, N.C. Polfer, Insights into the fragmentation pathways of gas-phase protonated sulfoserine, Int. J. Mass Spectrom. 379 (2015) 26-32.

[19] M. Rožman, Aspartic acid side chain effect - experimental and theoretical insight, J. Am. Soc. Mass Spectrom. 18 (2007) 121-127.

[20] K.A. Herrmann, V.H. Wysocki, E.R. Vorpagel, Computational investigation and hydrogen/deuterium exchange of the fixed charge derivative tris $2,4,6$ trimethoxyphenyl) phosphonium: implications for the aspartic acid cleavage mechanism, J. Am. Soc. Mass Spectrom. 16 (2005) 1067-1080.

[21] A.G. Baboul, L.A. Curtiss, P.C. Redfern, K. Raghavachari, Gaussian-3 theory using density functional geometries and zero-point energies, J. Chem. Phys. 110 (1999) 7650-7657.

[22] M. Rožman, S.J. Gaskell, Non-covalent interactions of alkali metal cations with singly charged tryptic peptides, J. Mass. Spectrom. 45 (2010) 1409-1415.

[23] M.J. Frisch, G.W. Trucks, H.B. Schlegel, G.E. Scuseria, M.A. Robb, J.R. Cheeseman, J.A. Montgomery Jr., T. Vreven, K.N. Kudin, J.C. Burant, J.M. Millam, S.S. Iyengar, J. Tomasi, V. Barone, B. Mennucci, M. Cossi, G. Scalmani, N. Rega, G.A. Petersson, H. Nakatsuji, M. Hada, M. Ehara, K. Toyota, R. Fukuda, J. Hasegawa, M. Ishida, T. Nakajima, Y. Honda, O. Kitao, H. Nakai, M. Klene, X. Li, J.E. Knox, H.P. Hratchian, J.B. Cross, C. Adamo, J. Jaramillo, R. Gomperts, R.E. Stratmann, O. Yazyev, A.J. Austin, R. Cammi, C. Pomelli, J.W. Ochterski, P.Y. Ayala, K. Morokuma, G.A. Voth, P. Salvador, J.J. Dannenberg, V.G. Zakrzewski, S. Dapprich, A.D. Daniels, M.C. Strain, O. Farkas, D.K. Malick, A.D. Rabuck, K. Raghavachari, J.B. Foresman, J.V. Ortiz, Q. Cui, A.G. Baboul, S. Clifford, J. Cioslowski, B.B. Stefanov, G. Liu, A. 
Liashenko, P. Piskorz, I. Komaromi, R.L. Martin, D.J. Fox, T. Keith, M.A. Al-Laham, C.Y. Peng, A. Nanayakkara, M. Challacombe, P.M.W. Gill, B. Johnson, W. Chen, M.W. Wong, C. Gonzalez, J.A. Pople, Gaussian 09, Gaussian, Inc., Pittsburgh, PA, 2009.

[24] D.A. Case, T.A. Darden, T.E. Cheatham III, C.L. Simmerling, J. Wang, R.E. Duke, R. Luo, R.C. Walker, W. Zhang, K.M. Merz, B. Roberts, S. Hayik, A. Roitberg, G. Seabra, J. Swails, A.W. Goetz, I. Kolossvai, K.F. Wong, F. Paesani, J. Vanicek, R.M. Wolf, J. Liu, X. Wu, S.R. Brozell, T. Steinbrecher, H. Gohlke, Q. Cai, X. Ye, J. Wang, M.-J. Hsieh, G. Cui, D.R. Roe, D.H. Mathews, M.G. Seetin, R. Salomon-Ferrer, C. Sagui, V. Babin, T. Luchko, S. Gusarov, A. Kovalenko, P.A. Kollman, AMBER 12, University of California, San Francisco, 2012.

[25] L. Drahos, K. Vékey, MassKinetics: a theoretical model of mass spectra incorporating physical processes, reaction kinetics and mathematical descriptions, J. Mass Spectrom. 36 (2001) 237-263.
[26] J. Laskin, R.P.W. Kong, T. Song, I.K. Chu, Effect of the basic residue on the energetics and dynamics of dissociation of phosphopeptides, Int. J. Mass Spectrom. 295 (2012) 330-332

[27] K. Vékey, A. Somogyi, V.H. Wysocki, Average activation energies of lowenergy fragmentation processes of protonated peptides determined by a new approach, Rapid Commun. Mass Spectrom. 10 (1996) 911-918.

[28] J. Laskin, T.H. Bailey, J.H. Futrell, Fragmentation energetics for angiotensin and its analogs from time- and energy-resolved surface-induced dissociation studies, Int. J. Mass Spectrom. 234 (2004) 89-99.

[29] W. Reusch, Virtual Textbook of Organic Chemistry, Department of Chemistry, Michigan State University, http:// www2.chemistry.msu.edu/faculty/reusch/ VirtTxtJml/react2.htm\#rx6 